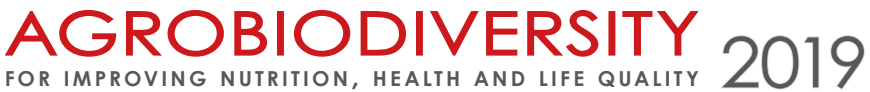

(3)

\section{STOMATAL STRUCTURE IN SOLIDAGO L. SPECIES AS THE INDEX OF THEIR ADAPTATION OPPORTUNITIES}

\author{
Vinogradova Yulia ${ }^{1}$, Grygorieva Olga* ${ }^{2}$, Vergun Olena ${ }^{2}$ \\ ${ }^{1}$ N.V. Tsitsin Main Botanical Garden of Russian Academy of Sciences, Moscow, Russia \\ ${ }^{2}$ M.M. Gryshko National Botanical Garden of National Academy of Sciences of Ukraine
}

Received: 25. 11. 2019 Revised: . 25. 11. 2019 Published: 30. 11. 2019

The study of the adaptability of alien plant species is very important. According to this characteristic there is possible to forecast their further spreading in the secondary distribution range. This is especially relevant for the species having already "escaped" from cultivation and started actively invading the natural communities. Well known that the structure of the leaf blade reflects the adaptability of the species. The purpose of this study is to compare the stomatal structure of cultivated Solidago L. species to assess their adaptive capacity. Alien specimens from the collection of Padova botanical garden (Italy): S. altissima L., S. caesia L., S. canadensis L., S. graminifolia(L.) Salisb., S. juncea Aiton, S. latifolia L., S. lepida DC., S. rugosa Mill., S. sempervirens L., S. serotinoides Á. Löve \& D. Löve (= S. gigantea var. leiophylla Fernald), S. uliginosa Nutt. were the objects of the study. The stomata were characterized by 21 quantitative characteristics. Various strategies were being implemented to increase the total transpiration area of plants: increasing the size of stomata; increasing the number of stomata; increasing the area of the leaf blade; increasing the number of leaves on the shoot; increasing the number of the shoots. In terms of the relative transpiration area index $\left(I_{o t}, \%\right)$, the species are divided into three groups with a high (25-50), medium (15-25) and low $(<15) I_{o t^{*}}$ Our article is considered as a basis for monitoring the dissemination of alien species. The high value of $I_{o t}$ indicates the greater adaptiveness of alien species and can be used to predict the further expansion of their secondary distribution range and increase the chances of transforming into an invasive taxon.

Keywords: Solidago, leaves, stoma, invasion plants

\section{Introduction}

North American Solidago L. species have been cultivated in European botanical gardens since the end of the $17^{\text {th }}$ century (Kowarik, 2003). The most complete collection of this genus is represented in the oldest botanical garden of Europe - in Padua (Italy). The garden was established in 1545 by the decision of the Venetian Senate with the aim of growing "medicinal herbs" for the Faculty of Medicine of the University of Padua. In 1997, like the "prototype of all botanic gardens", it was listed by UNESCO as a World Heritage Site (Buffa et al., 1999).

\footnotetext{
*Corresponding author: Olga Grygorieva, M.M. Gryshko National Botanical Garden of National Academy of Sciences of Ukraine, Timiryazevska 1, 01014 Kyiv, Ukraine $\triangle$ olgrygorieva@gmail.com
} 
Solidago altissima L., S. caesia L., S. canadensis L., S. graminifolia (L.) Salisb., S. juncea Aiton, S. latifolia L., S. lepida DC., S. rugosa Mill., S. sempervirens L., S. serotinoides Á. Löve \& D. Löve (= S. gigantea var. leiophylla Fernald) and $S$. uliginosa Nutt. grow in the historic part of the garden. All these species naturally grow on the territory of North America and have established into Europe through an intentional introduction. Three of them (S. altissima, S. canadensis, and $S$. gigantea) are naturalized in Europe (Tutin et al., 1976) and invaded the natural phytocenoses, i.e. belong to the group of invasive species (Lambdon et al., 2008; Vinogradova et al., 2010). In recent years $S$. graminifolia has been an active expansion of the secondary distribution range. It is marked as invasive in Poland and Belarus. The aboriginal $S$. virgaurea L. is included in the collection, too.

The quantitative characteristics of stomata are highly dependent on environmental conditions; therefore, it is not always possible to carry out a comparative analysis of different taxa on these parameters. Here, in the Botanical Garden of Padua, the plants grow side by side, on the same agricultural background, in partial shade. This allows comparing the characteristics of the stomatal apparatus of various species. It is known that the adaptive capacity of plants can be assessed by the morpho-anatomical feathers of the leaves (Marin et al., 1988; Kiseleva, 2009; Egorova et al., 2016; Vinogradova et al., 2018). For example, a small number of stomata and their small size provide the permanent opening of stomata and excessive transpiration, which may indicate low adaptability of plants to light and humidity conditions. The correlation between some micromorphological structures and the degree of plant's adaptation to various ecological conditions is proved for many species: Crataegus spp. (Foroughbakhch et al., 2000; Ganeva et al., 2009), Calystegia soldanella (L.) Roem. \& Schult., Euphorbia paralias L. and Otanthus maritimus L. (Ciccarelli et al., 2009), Amelanchier ovalis Medic (Ganeva and Uzunova, 2010b), Prunus armeniaca L. (Laajimi et al., 2011), Pinus roxburghii Sarg. (Tiwari et al., 2013), Mespilus germanica L. (Koçyiğit et al., 2015), Cornus spp. (Klymenko and Klymenko, 2017), Typha domingensis Pers. (Akhta et al., 2017), Cydonia oblonga Mill., Pseudocydonia sinensis (Thouin) C.K. Schneid. and Chaenomeles japonica (Thunb.) Lindl. ex Spach (Vinogradova et al., 2018).

The evaluation of adaptive capacity is very relevant for alien species. It gives a possibility to predict the further expansion of their secondary distribution range. For genus Solidago, this is doubly relevant since already several species of this genus "escape" from cultivation and began to be actively invaded the natural cenoses. There are data on the leave's structure only for alien $S$. canadensis, $S$. gigantea (= S. serotinoides) and S. graminifolia as well as aborigen S. virgaurea (Szymura and Wolsky, 2011; Vinogradova, 2012). Data for other Solidago spp. concerned only macromorphology of these species (Weber, 2000). Our work is the first study of leaf anatomy for the most part of Solidago spp., which is cultivated in Europe.

The purpose of this work is a comparative analysis of the stomatal characteristics of cultivated Solidago species to assess the adaptive capabilities of these alien species. 


\section{Material and methods}

\section{Plant material}

Samples of the following alien Solidago species from the collection of the botanical garden in Padua are the objects of the study: S. altissima, S. caesia, S. canadensis, S. graminifolia, S. juncea, S. latifolia, S. lepida, S. rugosa, S. sempervirens, S. serotinoides, and S. uliginosa. During the visit to the garden at the beginning of June 2017, we collected leaves per each species. For the analysis, 3 shoots of each species were selected, and from each shoot 3 leaves were selected from the basal part of the stem (total 9 leaves per each species).

\section{Ultrastructure of leaves}

To study the features of the stomatal apparatus, the method of obtaining lacquer replicas was used. Unfortunately, it was not possible to obtain clear prints of the epidermis in S. latifolia due to a thin wax coating covering the leaves, and this species is not included in our study. The following micro-morphological features were analyzed: the number of guard cell of the stoma, the length of the polar axis of the stoma $(I)$, the length of the equatorial diameter $(d)$, the shape of the stomata (by the ratio $l / d$ ), the area of the one stoma ( $s$ ellipse $=\pi(l / 2)(d / 2)$ ), the number of stomata in the field of the microscope view $(n)$, the total transpiratory area $(=s \times n)$. The relative transpiration area (relative transpiration index, $I_{o t}$ ) was calculated as the ratio of the total average transpiration area to the total area of the underside of the leaf blade, according to the formula:

$$
I_{o t}=\frac{\sum n \pi L D}{\sum S} 100 \%
$$

These seven signs were studied for both the upper and lower sides of the leaf blade, and then their ratio was determined. Thus, the stomatal apparatus of 10 species are characterized by 21 quantitative traits.

Morphology of the stomatal apparatus was examined with the Keyence VHX-1000E digital microscope. The number of stomata in the field of the microscope view with an increase of $\times 1,500$ was determined in 10 replicates. The total number of stomata for each species to determine their size is $50-100$.

\section{Analysis of data}

Basic statistical analyses were performed using PAST 3.15. Data were submitted ANOVA and differences between means compared through the Tukey-Kramer test $(\alpha=0.05)$. All data are presented as $\mathrm{M} \pm \mathrm{m}$, where $M$ - arithmetic average, $m$ - arithmetic average deviation.

\section{Results and discussions}

The size of the leaf blades in the studied species decreases in the following order: $S$. sempervirens $\rightarrow$ S. juncea $\rightarrow$ S. altissima $\rightarrow$ S. serotinoides $\rightarrow$ S. canadensis $\rightarrow$ S. rugosa $\rightarrow$ S. lepida $\rightarrow$ S. caesia $\rightarrow$ S. uliginosa $\rightarrow$ S. graminifolia. In three species (S. altissima, S. canadensis, and $S$. rugosa) the leaves are amphystomatic, i.e. the stomata are located only on the lower 
Vinogradova, Y., Grygorieva, O., Vergun, 0.

Agr.bio.div. Impr. Nut., Health Life Qual., 2019, 101-110

(abaxial) side of the leaf; in other species, the leaves are hypostomatic, and the stomata are located on both the lower and the upper (adaxial) side of the leaf blade (Figure 1A, B).
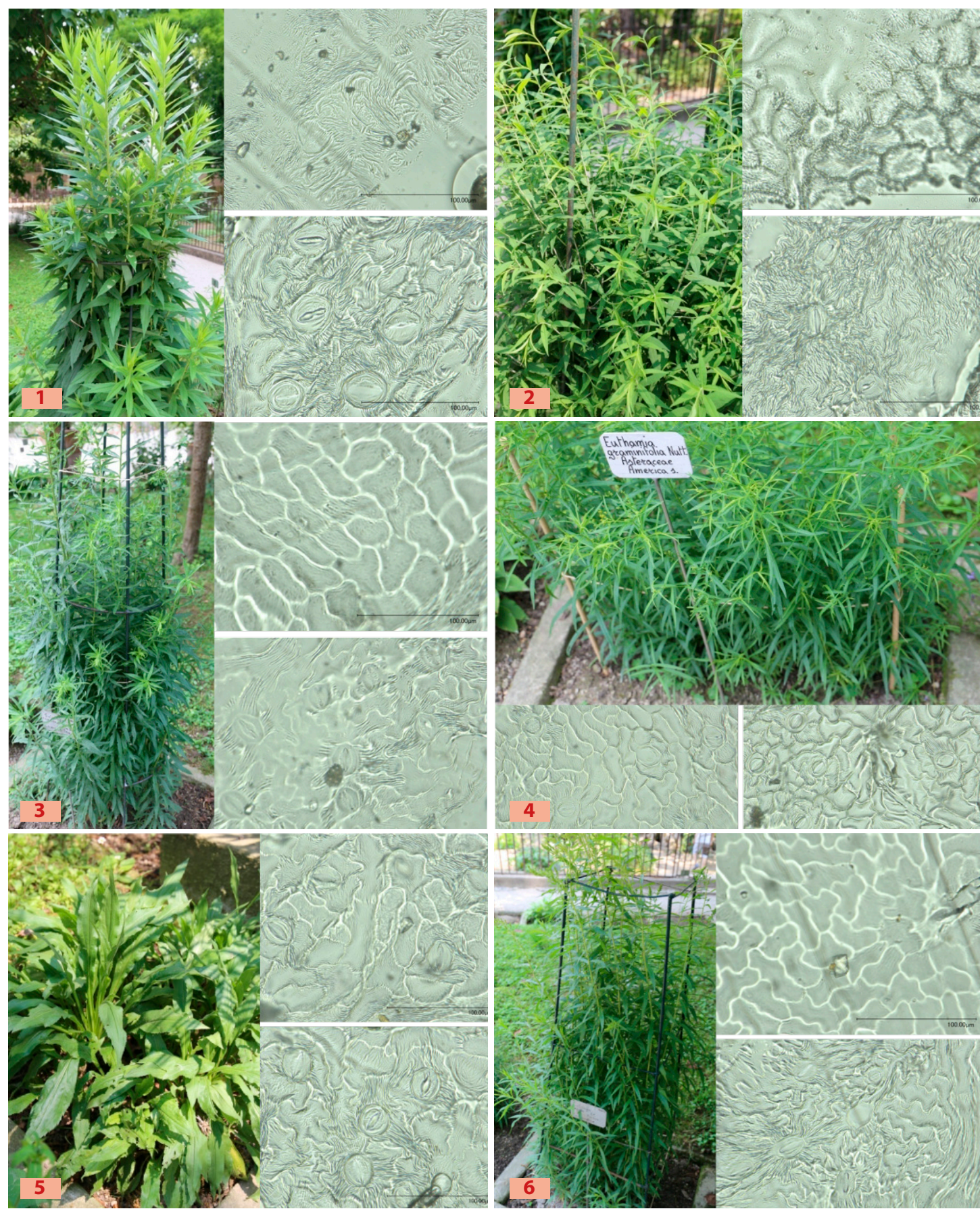

Figure 1A Plant habitus and microphotographs of stomata on the abaxial and adaxial side of the leaf blade 1 - Solidago altissima L.; 2 - Solidago caesia L.; 3 - Solidago canadensis L.; 4 - Solidago graminifolia (L.) Salisb.; 5 - Solidago juncea Aiton; 6 - Solidago lepida DC. 
Vinogradova, Y., Grygorieva, O., Vergun, O.

Agr.bio.div. Impr. Nut., Health Life Qual., 2019, 101-110
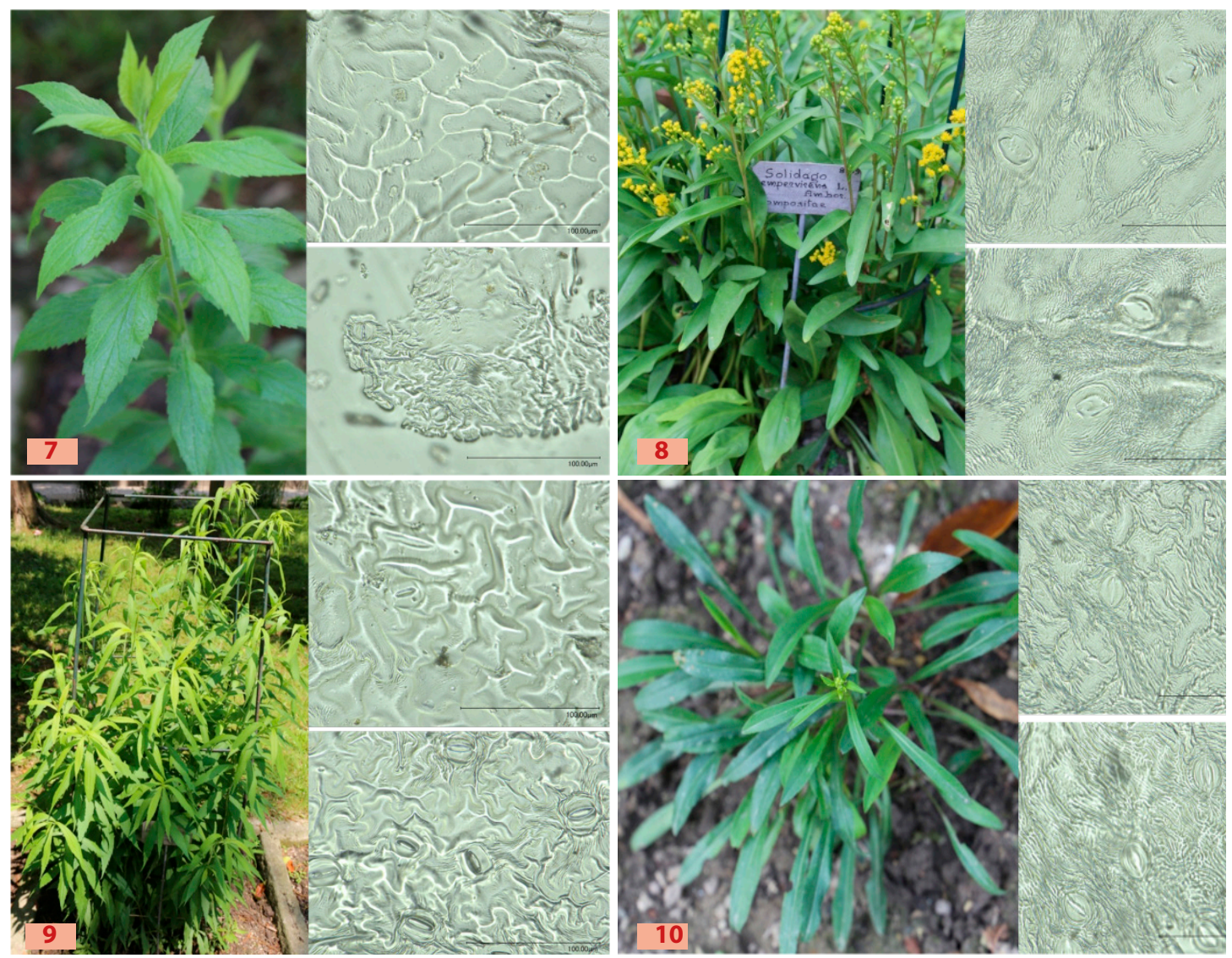

Figure 1B Plant habitus and microphotographs of stomata on the abaxial and adaxial side of the leaf blade 7 - Solidago rugosa Mill.; 8 - Solidago sempervirens L.; 9 - Solidago serotinoides Á. Löve \& D. Löve; 10 Solidago uliginosa Nutt.

The samples were significantly divided into 2 groups (Figure 2, Table 1), according to the size of stomata from the abaxial side of the leaf blade. The first group, characterized by large stomata (36-40 × 28-30 $\mu \mathrm{m})$, includes $S$. sempervirens, $S$. altissima, and S. juncea.

All other species are included in the second group (19-28 × 16-22 $\mu \mathrm{m})$, with the exception of $S$. serotinoides. $S$. serotinoides are distinguished by the highest variability of this feature (27-41 $\times 20-34 \mu \mathrm{m})$ and in Figure 2 is not even displayed since it occupies an intermediate position between the two groups and overlaps all other samples.

In most samples, the shape of the stomata is rounded: the ratio of the average length of the polar axis to the average length of the equatorial diameter is 1.2-1.4. Only in S. serotinoides on the adaxial side of the leaf blade, stomata are elongated, and this ratio is 1.7. 
Vinogradova, Y., Grygorieva, O., Vergun, 0.

Agr.bio.div. Impr. Nut., Health Life Qual., 2019, 101-110

Table 1 Quantitative characteristic of stomata in Solidago L. species

\begin{tabular}{|c|c|c|c|c|c|c|c|c|c|}
\hline \multirow[t]{2}{*}{ Species } & \multicolumn{3}{|c|}{ Polar axis $(I)(\mu \mathrm{m})$} & \multicolumn{3}{|c|}{ Equatorial diameter $(d)(\mu \mathrm{m})$} & \multicolumn{3}{|c|}{$l / d$} \\
\hline & $\min$ & $\max$ & $\bar{x} \pm \mathrm{S} x$ & $\min$ & $\max$ & $\bar{x} \pm S x$ & $\min$ & $\max$ & $\bar{x} \pm S x$ \\
\hline & \multicolumn{9}{|c|}{ Abaxial side of the leaf blade } \\
\hline S. sempervirens & 36 & 44 & $39.7 \pm 0.8$ & 25 & 36 & $30.3 \pm 0.8$ & 1.0 & 1.5 & $1.3 \pm 0.0$ \\
\hline S. altissima & 26 & 51 & $36.4 \pm 0.8$ & 23 & 31 & $27.7 \pm 0.4$ & 1.1 & 1.9 & $1.3 \pm 0.0$ \\
\hline S. juncea & 29 & 37 & $32.6 \pm 0.4$ & 24 & 32 & $28.2 \pm 0.4$ & 1.0 & 1.3 & $1.2 \pm 0.0$ \\
\hline S. uliginosa & 23 & 36 & $27.7 \pm 0.7$ & 17 & 25 & $21.6 \pm 0.4$ & 1.1 & 1.6 & $1.3 \pm 0.0$ \\
\hline S. caesia & 18 & 30 & $26.3 \pm 0.7$ & 14 & 23 & $20.0 \pm 0.7$ & 1.1 & 1.6 & $1.3 \pm 0.0$ \\
\hline S. canadensis & 21 & 32 & $26.3 \pm 0.6$ & 15 & 28 & $20.2 \pm 0.4$ & 0.9 & 2.1 & $1.3 \pm 0.0$ \\
\hline S. lepida & 17 & 28 & $23.9 \pm 0.5$ & 11 & 21 & $18.0 \pm 0.4$ & 1.0 & 1.9 & $1.3 \pm 0.0$ \\
\hline S. graminifolia & 17 & 25 & $22.6 \pm 0.4$ & 13 & 23 & $19.0 \pm 0.4$ & 1.0 & 1.8 & $1.2 \pm 0.0$ \\
\hline S. rugosa & 14 & 28 & $19.4 \pm 1.2$ & 11 & 21 & $15.9 \pm 0.8$ & 0.9 & 1.5 & $1.2 \pm 0.0$ \\
\hline S. serotinoides & 27 & 41 & $32.8 \pm 0.9$ & 20 & 34 & $24.5 \pm 0.8$ & 1.0 & 2.0 & $1.4 \pm 0.1$ \\
\hline \multicolumn{10}{|c|}{ Adaxial side of the leaf blade } \\
\hline S. sempervirens & 33 & 42 & $37.1 \pm 0.6$ & 27 & 35 & $30.3 \pm 0.4$ & 1.1 & 1.4 & $1.2 \pm 0.0$ \\
\hline S. altissima & \multicolumn{9}{|c|}{ stomata are absent } \\
\hline S. juncea & 28 & 43 & $33.5 \pm 0.9$ & 18 & 30 & $25.5 \pm 0.8$ & 1.1 & 1.8 & $1.3 \pm 0.1$ \\
\hline S. uliginosa & 21 & 32 & $24.9 \pm 1.0$ & 19 & 23 & $21.3 \pm 0.4$ & 1.0 & 1.5 & $1.2 \pm 0.1$ \\
\hline S. caesia & 23 & 25 & $24.3 \pm 0.7$ & 14 & 20 & $17.3 \pm 1.8$ & 1.3 & 1.6 & $1.4 \pm 0.1$ \\
\hline S. canadensis & \multicolumn{9}{|c|}{ only one stoma } \\
\hline S. lepida & 18 & 27 & $23.2 \pm 0.5$ & 15 & 23 & $17.4 \pm 0.5$ & 1.1 & 1.7 & $1.3 \pm 0.0$ \\
\hline S. graminifolia & 18 & 27 & $23.1 \pm 0.3$ & 13 & 23 & $19.0 \pm 0.4$ & 1.0 & 1.8 & $1.2 \pm 0.0$ \\
\hline S. rugosa & \multicolumn{9}{|c|}{ stomata are absent } \\
\hline S. serotinoides & 26 & 31 & $29.0 \pm 1.5$ & 15 & 18 & $17.0 \pm 1.0$ & 1.4 & 2.0 & $1.7 \pm 0.2$ \\
\hline
\end{tabular}

Note: min, max - minimal and maximal measured values; $\bar{x}$ - arithmetic mean; $\mathrm{S} x$ - standard error of the mean

The most species (5 of 7) have hypostomatic leaves, i.e., the number of stomata is greater on the abaxial side of the leaf than on the adaxial side, and stomata are larger (Figure 2). In S. graminifolia, the size of the stomata on the adaxial and the abaxial side of the leaf blade is not significantly different, and the number of stomata on the underside of the leaf (average 5.6) is lower than on the adaxial side (average 6.8 in the field of the microscope view). In S. sempervirens, the stomata on the abaxial side of the leaf are larger than on the adaxial one (as for the most species), but their number on the abaxial side (as in S. graminifolia) is lower than on the adaxial side (2.4 contrary 3.0). These parameters are shown in Figure 3, 4 . 
Vinogradova, Y., Grygorieva, O., Vergun, O.

Agr.bio.div. Impr. Nut., Health Life Qual., 2019, 101-110

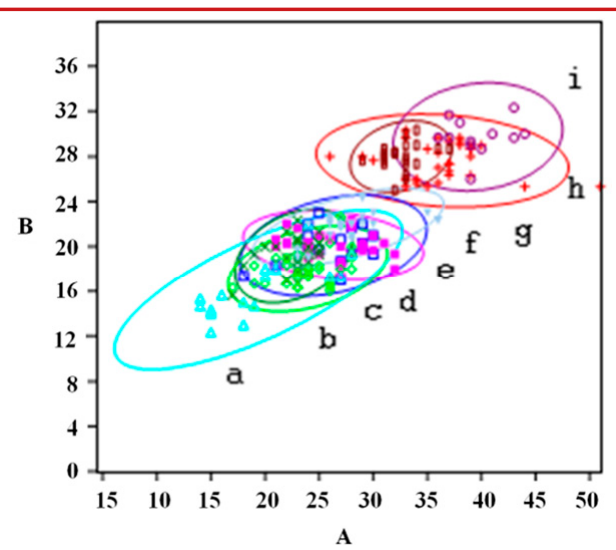

Figure 2 The stomatal size of Solidago species on the underside of the leaf blade

a - Solidago rugosa Mill.; b - Solidago graminifolia (L.) Salisb.; c - Solidago lepida DC.; - Solidago canadensis

L.; e - Solidago caesia L.; f - Solidago uliginosa Nutt.; g - Solidago juncea Aiton; h - Solidago altissima L.; $\mathrm{i}$ - Solidago sempervirens $\mathrm{L}$.

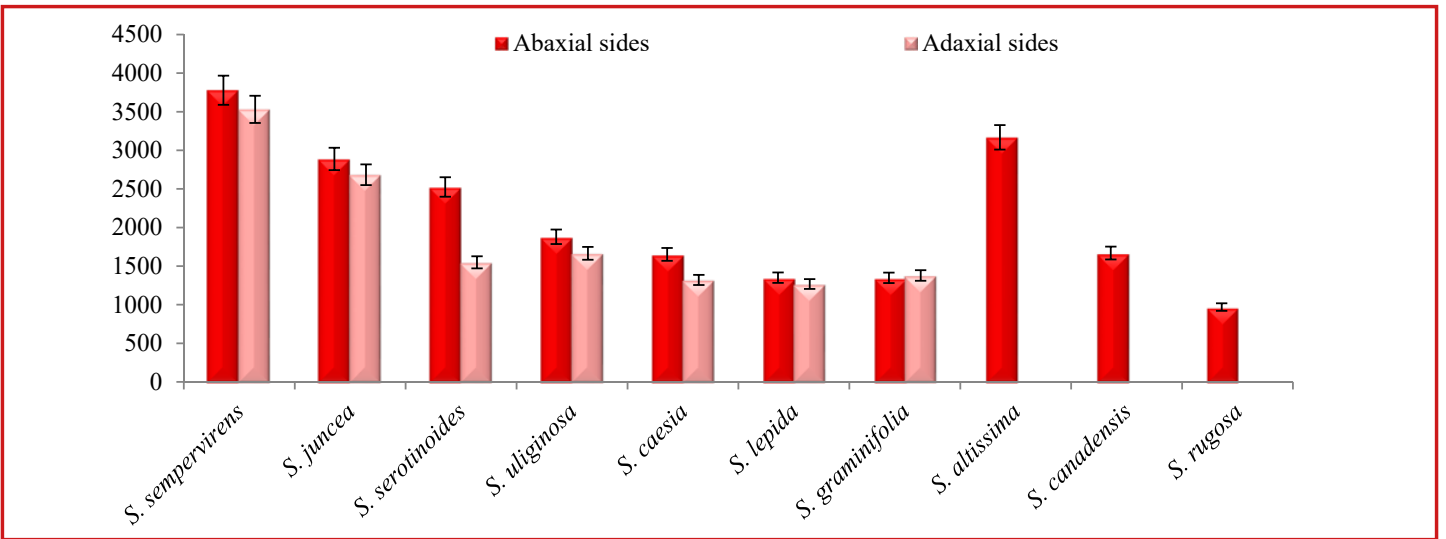

Figure 3 The average area of the one stoma on the leaf blades of Solidago spp. $\left(\mu \mathrm{m}^{2}\right.$ ) (each value represents the mean of three independent experiments $( \pm$ SD)

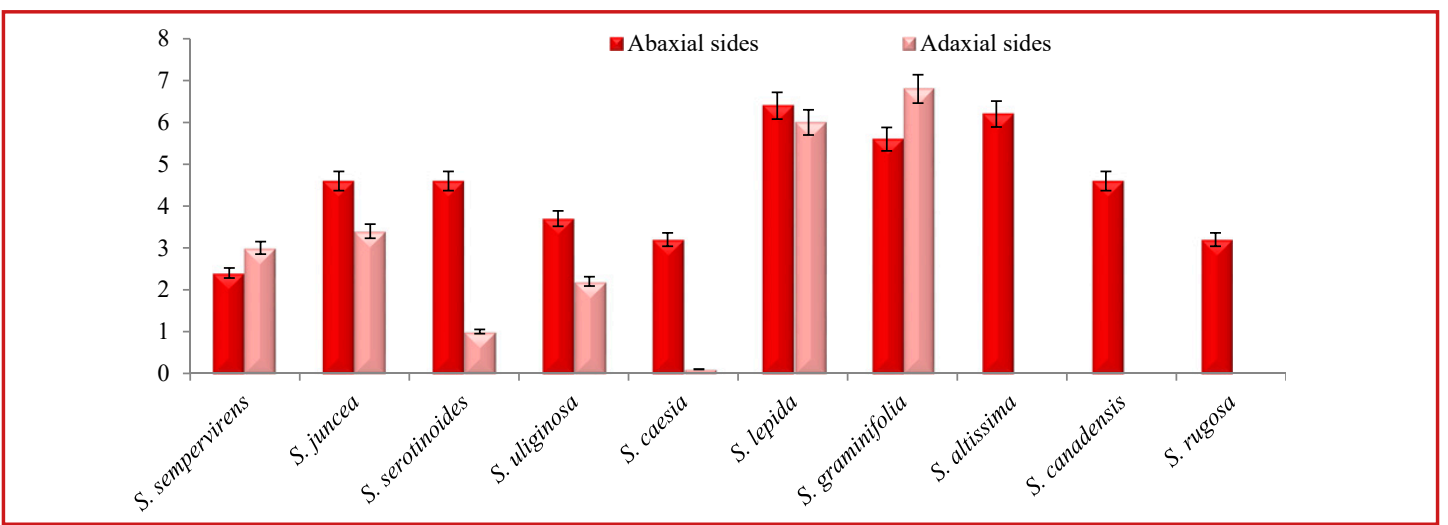

Figure 4 The average number of stomata in the field of the microscope on the leaf blades of Solidago spp. (each value represents the mean of three independent experiments $( \pm S D)$ 
When comparing these two figures, it is clearly seen that the average area of one stoma negatively correlates with the average number of stomata, therefore the variability of the average transpiration area is relatively low (Figure 5). In order to make a correct comparison of species over the area of transpiration, the relative transpiration index $\left(I_{o t}\right)$ have been calculated: the ratio of the total average transpiration area to the total area of the abaxial side of the leaf blade.

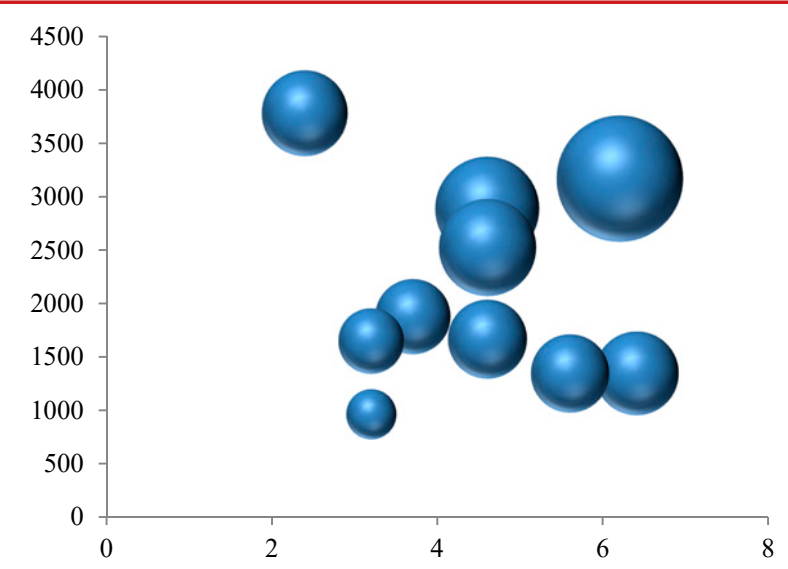

Figure 5 The average total transpiration area in the field of view of the microscope on the underside of the leaf blade of Solidago spp. $\left(\mu \mathrm{m}^{2}\right)$

According to this index $I_{o t}$, the studied species line up in the following order (\%): S. altissima (50), S. juncea (34), S. serotinoides (29), S. sempervirens (23), S. lepida (22), S. canadensis (19), S. graminifolia (19), S. uliginosa (18), S. caesia (13) and S. rugosa (8).

Our data on the stomatal characteristics in various Solidago species are correlated quite well with the invasive activity of these taxa. In this respect, the relative transpiration area index is especially indicative. S. altissima and $S$. serotinoides, which are widespread in the secondary distribution range, have at the same time the largest relative transpiration area (from 25 to $50 \%)$. S. juncea, which also has a high value of this indicator, is already beginning to be invaded the natural cenoses of Russia. This species was collected by A.A. Notov in the Tver region (Herbarium collections MW, MHA). S. sempervirens, S. lepida and S. uliginosa have an index from 15 to $25 \%$. They are similar on this parameter with the invasive $S$. canadensis and S. graminifolia, they are able to adapt well to the conditions of the Old World. They are less decorative and their presentation in the culture is not enough. This prevents (for now!) to the wide distribution of these species. $S$. caesia and $S$. rugosa are poorly adapted to the conditions of the new homeland $\left(I_{o t}<15 \%\right)$, the latter also had short shoots with few leaves in the beds in the Padua Botanical Garden.

Thus, we can take into consideration the stomatal structure (in addition to other features) for the prediction of the possible expansion of some alien species in their secondary distribution range. If an alien species has $I_{o t}>25 \%$, it is more likely to transform into an invasive taxon. Such species require stronger control measures of their dissemination. 


\section{Conclusions}

In Solidago species cultivated in the Botanical Garden of Padua, the size of stomata is generally negatively correlated with the average number of stomata. Various strategies are being implemented to increase the total transpiration area of the plants. At the cellular level, this is an increase in stoma size (S. sempervirens, S. altissima, S. juncea) and an increase in the number of stomata (S. altissima) up to the formation of hypostomatic leaves, i.e. the location of numerous stomata on both sides of the leaf blade (S. lepida, S. graminifolia). At the organism level, the strategy of alien species is either to increase the area of the leaf blade, which is especially characteristic of rosette leaves ( $S$. sempervirens, $S$. juncea, $S$. uliginosa), or to increase the number of leaves on the shoot (S. lepida) or to increase the number of shoots (S. serotinoides, S. graminifolia). According to the index of the relative area of transpiration, species are divided into a group with a high (25-50\%) relative area of transpiration (S. altissima, S. serotinoides, S. juncea), an average (15-25\%) area (S. sempervirens, S. lepida, S. uliginos, S. canadensis, and S. graminifolia) and a low (less than 15\%) relative area of transpiration (S. caesia and S. rugosa).

The high value of the index of the relative area of transpiration indicates greater adaptability of alien species and can (among other features) be used to predict the further expansion of their secondary distribution range and increase the chances to transform into an invasive taxon.

\section{Acknowledgements}

The authors express their deep appreciation to the curators of the plant collections and the Director of the Botanical Garden of Padua. We also thank Yu.A. Tsyplakov'a for her help in collecting the plant material. The work was carried out in accordance with the MBG RAS Research Project No. 118021490111-5 and partly supported by the Russian Foundation for Basic Research, grant 18-04-00411. Co-authors are grateful to the National Scholarship Programme of the Slovak Republic for the scholarship grant for the research stay during which the presented knowledge was obtained.

\section{References}

AKHTA, R.N., HAMEED, M., AWAZ, F., AHMAD, K.SH., HAMID, A., SEGOVIA-SALCEDO, C., SHAHNAZ, M.M. 2017. Leaf anatomical and biochemical adaptations in Typha domingensis Pers. ecotypes for salinity tolerance. In Botanical Sciences, vol. 95(4), p. 807-821.

BUFFA, G., BRACCO, F., TORNADORE, N. 1999. Guida all'Orto Botanico di Padova. Quattro percorsi per conoscerne la storia e le piante. Centrooffset, Padova. $18 \mathrm{p}$.

CICCARELLI, D., COSTANTINA FORINO, L.M., BALESTRI, M., PAGNI, A.M. 2009. Leaf anatomical adaptations of Calystegia soldanella, Euphorbia paralias and Otanthus maritimusto the ecological conditions of coastal sand dune systems. In Caryologia, vol. 62(2), p. 142-151.

DRISCOLL, S.P., PRINS, A., OLMOS, E., KUNERT, K.J., FOYER, C.H. 2006. Specification of adaxial and abaxial stomata, epidermal structure and photosynthesis to $\mathrm{CO}_{2}$ enrichment in maize leaves. In Journal of Experimental Botany, vol. 57(2), p. 381-390.

EENSALU, E. 2008. Acclimation of stomatal structure and function in tree canopy: effect of light and $\mathrm{CO}_{2}$ concentration. University of Tartu. DSpace Repository. 
Vinogradova, Y., Grygorieva, O., Vergun, $O$.

Agr.bio.div. Impr. Nut., Health Life Qual., 2019, 101-110

FOROUGHBAKHCH, R., MAITI, R., GUTIÉRREZ-LOBATOS, J.L., BORYS, M., HAUAD, L., HERNANDEZPIÑERO, J.L., BADII, M.H., ALBA-AVILA, J.A. 2000. Uses and morphological characters of Crataegus pubescens HBK (Rosaceae : Maloideae) in Mexico. In Phyton, vol. 69(1), p. 11-15.

GANEVA, T., UZUNOVA, K., KOLEVA, D. 2010. Comparative leaf epidermis investigation in species of genus Crataegus L. (Rosaceae) from Bulgaria. In Feddes Repert, vol. 120, p. 169-184.

GANEVA, T., UZUNOVA, K. 2010. Leaf epidermis structure in Amelanchier ovalis Medic. (Rosaceae). In Biotechnol Biotechnol Eq., vol. 24, p. 36-38.

KISELEVA, N.S. 2009. Estimation of adaptability in different pear genotypes on morpho-anatomical and physiological state of leaves. In Ser. Biologiya Rasteniy, vol. 3, p. 34-38.

KLYMENKO, S., KLYMENKO, 0. 2017. Leaf anatomy of the members of Cornaceae family in conditions of the Forest-Steppe of Ukraine. In Annals of Romanian Society for Cell Biology, vol. 21(2), p. 28-39.

KOÇYIĞIT, M., BÜYÜKKILIÇ, B., ALTINBAŞAK, O., UBUL, N. 2015. Comparative leaf anatomy of three food plants that are used medically; Mespilus germanica L., Malus sylvestris (L.) Mill. subsp. orientalis and Cydonia oblonga Mill. (Rosaceae). In Fac. Pharm. Istanbul., vol. 46(1), p. 39-48.

KOWARIK, I. 2003. Biologische Invasionen: Neophyten und Neozoen in Mitteleuropa. Ulmer, Stuttgart. $380 \mathrm{~s}$.

LAAJIMI, N.O., BOUSSADIA, O., SKHIRI, F.H., TEIXEIRA DA SILVA, J.A., REZGUI, S., HELLALI, R. 2011. Anatomical Adaptations in Vegetative Structures of Apricot Tree (Prunus armeniaca L.) cv. 'Amor El Euch' Grown under Water Stress. In Fruit, Vegetable and Cereal Science and Biotechnology, vol. 5(2), p. 46-51.

LAMBDON, P.W., PYŠEK, P., BASNOU, C., HEJDA, M., ARIANOUTSOU, M., ESSL, F., JAROŠÍK, V., PERGL, J., WINTER, M., ANASTASIU, P., ANDRIOPOULOS, P., BAZOS, I., BRUNDU, G., CELESTI-GRAPOW, L., CHASSOT, P., DELIPETROU, P., JOSEFSSON, M., KARK, S., KLOTZ, S., KOKKORIS, Y., KÜHN, I., MARCHANTE, H., PERGLOVÁ, I., PINO, J., VILA, M., ZIKOS, A., ROY, D., HULME, PH.E. 2008. Alien flora of Europe: species diversity, temporal trends, geographical patterns and research needs. In Preslia, vol. 80, p. 101-149.

MARIN, J.A., GELLA, R., HERRERO, M. 1988. Stomatal Structure and Functioning as a Response to Environmental Changes in Acclimatized Micropropagated Prunus cerasus L. In Annals of Botany, vol. 62(6), p. 663-670.

SZYMURA, M., WOLSKY, K. 2011. Leaf epidermis traits as tools to identify Solidago L. taxa in Poland. In Acta Biologica Cracoviensia. Ser. Botanica, vol. 53(1), p. 38-46.

TIWARI, S.P., KUMAR, P., YADAV, D., CHAUHAN, D.K. 2013. Comparative morphological, epidermal, and anatomical studies of Pinus roxburghii needles at different altitudes in the North-West Indian Himalayas. In Turkish Journal of Botany, vol. 37, p. 65-73.

TUTIN, T.G., HEYWOOD, V.H., BURGES, N.A., VALENTINE, D.H., WALTERS, S.M., WEBB, D.A. 1976. Solidago L. In Flora Europaea, vol. 4, p. 110-111.

VINOGRADOVA, YU. K, MAYOROV, S.R., CHOROON, L.V. 2010. Black book of flora of the Middle Russia. Geos Press, Moscow. 512 p.

VINOGRADOVA, YU.K., RIABCHENKO, A., GORBUNOV, YU., GRYGORIEVA, O., BRINDZA, J. 2018. Characteristic of stomata for Cydonia oblonga Mill., Pseudocydonia sinensis (Thouin) C.K. Schneid. and Chaenomeles japonica (Thunb.) Lindl. ex Spach species. In Annals of R.S.C.B., vol. 22(2), p. 18-25.

VINOGRADOVA, YU.K. 2012. Biodiversity of Solidago L. taxa by micromorphological features. In Biodiversity: Problems of Study and Conservation, p. 346-350.

WEBER, E. 2000. Biological flora of Central Europe: Solidago altissima L. In Flora. Switzerland, vol. 195, p. 123-134. 2000.

YEGOROVA, D.A., VINOGRADOVA, YU.K., GORBUNOV, YU.N., MOLKANOVA, O.I. 2016. Micropropagation of the albiflorous form Chamaenerion angustifolium (L.) Scop. and evaluation of its adaptive ability. In Vestnik Udmurtskogo universiteta, vol. 26(4), p. 25-31.

BUFFA, G., BRACCO, F., TORNADORE, N. 1999. Guida all'Orto Botanico di Padova. Quattro percorsi per conoscerne la storia e le piante. Centrooffset, Padova. $18 \mathrm{p}$. 